\title{
Rare species of psammophyte flora in transboundary areas of Southern Siberia and Mongolia
}

\author{
Vladimir Doronkin ${ }^{1}{ }^{*}$, Natalya Vlasova $^{1}$, Nanjidsuren Ochgere $^{2}$, Luvsanbaldan Enkhtuya ${ }^{2}$ \\ and Tovuudorj Munkh-Erdene ${ }^{2}$ \\ ${ }^{1}$ Central Siberian Botanical Garden, Siberian Branch of the Russian Academy of Sciences, \\ Zolotodolinskaya st., 101, 630090, Novosibirsk, Russian Federation \\ ${ }^{2}$ Institute of General and Experimental Biology, Mongolian Academy of Sciences, Jukov st., 77, \\ 210351, Ulaanbaatar, Mongolia
}

\begin{abstract}
Data on distribution of 3 rare species which occur in sandy arrays of cross-border territories of Southern Siberia and Mongolia are provided: Iris psammocola, Iris loczyi (Iridaceae) and Vicia tsydenii (Fabaceae), a brief characteristic of their cenopopulation is given.
\end{abstract}

The originality of the plant communities which occur in sandy arrays allows a number of authors to distinguish them as special florocenotype-psammophyton (Psammophyton) [1]. The structure of vegetative cover of sandy arrays considerably depends on the relief and degree of the substrate coherence [2]. In the south of the Tuva Republic in the reserved area "Ubsu-Nur Depression" the cluster of "Tsuger-Els" was investigated. It represents a sandy mane extended from the northwest to the southeast along the left riverbank of the Tes-Hem. To the northwest of mane there is big fresh lake Tore-Hol. Within the cluster a wavy undulating land prevails. The total area of Tsuger-Els sands covers about $60 \mathrm{~km}^{2}$. Similar arrays proceed also in the territory of Mongolia - the Altan-Els sands entering the largest array Borig-Del. The cluster belongs to Ubsunursky plain desert-steppe province [3]. In 2005 in the territory of Tsuge-Els cluster a new species for the flora of Russia - Iris psammocola Y.T. Zhao was found [4]. The species has obconical rhizome, flowers on short peduncles which are inside the curtain is characteristic of this species, is on 2 pedicel lanceolate webbed spata are available for each flower, the perianth tube is thin funnelshaped, many times exceeds the ovary at length, the flowers are sulfur-yellow. In 2013 in the neighborhood of lake Tore-Hol we also found this species: "Republic of Tuva, Erzinsky district, lake Tore-Hol neighborhood, Tsuger-Els sands, N 5009.231 'E 95 12.751', $\mathrm{H}=1200 \mathrm{~m}, 6.06 .2013$, V. Doronkin, N. Vlasova" (NSK). The plants occur in different plant aggregations of small structure and the rarefied herbage, at the same time the projective covering makes about 20\% in cenopopulation: Thymus mongolicus (Ronn.) Ronn. - sp., Carex sabulosa Turcz. ex Kunth - sol., Agropyron desertorum (Fisch. ex Link) Schult. sp., Thesium tuvense Krasnob. - sol., I. psammocola - sol.; in some about 30\%: Alissum lenense Adams - sol., Th. mongolicus - sol., Artemisia sp. - sol., Oxytropis tragacanthoides

${ }^{*}$ Corresponding author: norbo@ngs.ru 
Fisch. - sp., Gypsophila patrinii Ser. - sp., Orostachys spinosa (L.) C.A. Mey. - sol., I. psammocola - sp. The fullest data on vegetation of these areas are provided in the book "Steppes of Inner Asia" [5].

For the first time I. psammocola in Mongolia was found by us in 2013 at inspection of the adjacent territory: 1) "Mongolia, aimag Uvs, Altan-Els sands, N $49^{\circ} 46$ 'E 95 $13^{\prime}$ ', $\mathrm{H}=1370 \mathrm{~m}$, sand hills, 9.06.2013, L. Enkhtuya, T. Munkh-Erdene, V. Doronkin, N. Vlasova", 2) "sands of Borig-Del, N 49 50.26' E 94²0.53', H=1117 m, sandy barkhans, 11.06.2013, the same authors" (UBA, NSK) [6]. On sandy arrays of Altan-Els the projective covering in tsenopopulyation reached 30\%: I. psommocola - sol., Th. mongolicus - sol., Potentilla acaulis L. - cop. $\square$, Carex duriuscula C.A. Mey. - sp., Thesium refractum C.A. Mey. - sol., Artemisia frigida Willd. - sol., Koeleria altaica (Domin) Kryl. - sol., Agropyron cristatum (L.) Beauv. - sol. I. psommocola occurs only in sandy arrays: in Russia - the South of Tuva (Tsuger-Els sands), the South of Buryatia (surrounding Kyakhta), in Mongolia - the aimag Uvs (Altan-Els sands, Borig-Del sands), in China - the Tenger sands relating to the Alashan Desert. Thus, the species has disjunctive area in Central Asia.

Another rare species - Iris loczyi Kanitz also occurs only in the south of the Tuva Republic. The species has leaves greyish-green glaucous, rigid, twisting, the 1-3rd., flowers single blue-violet, nimbus tube up to $14 \mathrm{~cm}$ length. Its locations are known around lake Tore-Hol, the mountain Tsagan-Tologoy and Anchalau. It is found by us on border with Mongolia: "Republic of Tuva, Erzinsky district, valley of river Tes -Hem, N 49 59' E $95^{\circ} 30^{\prime}, \mathrm{H}=1280 \mathrm{~m}$, sandy arrays, 7.06.2013, V. Doronkin" (NSK).

The projective covering in some cenopopulation reaches from 20\%: I. loczyi - sol., Caragana bungei Ledeb. - sol., Carex duriuscula - sol., Koeleria cristata (L.) Pers. s.1. sp., Festuca valesiaca Gaudin - sp., up to 30\%: I. loczyi - sol., Festuca valesiaca - cop. $\square$, A. frigida - sp., P. acaulis - sol. The species in Mongolia was known only from Mongolian Altai [7], it was found by us also in the Botaniko-geographic region - Depression of Great Lakes: 1) "Mongolia, aimag Uvs, vicinities of the lake Bayan-Nour, N 49 56.790' $\mathrm{E}$ 94 04.522', H=940 m, Borig-Del sands, sandy barkhans, 10.06.2013, L. Enkhtuya, T. Munkh-Erdene, V. Doronkin, N. Vlasova, ", 2) in the same place, at Lake Boyan-nur, $\mathrm{N} \mathrm{50} 01.36^{\prime} \mathrm{E} 94^{\circ} 01.20^{\prime}, \mathrm{H}=994 \mathrm{~m}$, sands, 11.06.2013, the same authors " (UBA, NSK). The projective covering was from 20\%: I. loczyi - sol., Chamaerhodos sabulosa Bunge sol., P. acaulis - sol., up to 30\%: I. loczyi - sol., Ch. sabulosa - sp., Ephedra monosperma C.A. Mey. - sol., P. acaulis - sol., Astragalus brevifolius Ledeb. - sol., C. duriuscula - sol. Also the species is found in the Southwest part of Altan-Els sands: "Aimag Uvs, southwest part of Altan-Els sands, $\mathrm{N} 49^{\circ} 46.857^{\prime}$ E $95^{\circ} 06.049^{\prime}, \mathrm{H}=1200 \mathrm{~m}$, hilly sands, 12.06.2013, the same authors" (UBA, NSK). The projective covering made from 35\%: I. loczyi - sol., $F$. valesiaca - cop. $\square$, Artemisia obtusiloba Ledeb. - sol., Hypecoum erectum L. - sol., up to 30\%: I. loczyi - sol., Hypecoum erectum - sp., F. valesiaca - sol., Allium ramosum L. - sol. The species is widespread in Central Asia, in Southwest Asia, Mongolia, China. Locations in Tuva are the most northern.

Thus our researches confirm the data that the psammophytic complex of flora of Tuva is directly connected with the Mongolian flora which is explained by cross-border located array of Tsuger-Els [8].

Another area of psammophytes distribution - the South of the Buryatia Republic: Vicia tsydenii Malyschev is a rare species here. Low perennial approx. $20 \mathrm{~cm}$ of height, with thin long rhizome. The stalks are direct, branchy. The leaflets among 4-5 couples, oblong and obovate at 10-15 mm length, from below greyish due to the pressed beard of hairs. Flowers of 5-7 mm length, pinkish-violet, in friable brushes, beans wide with 1-2 seeds.

The species is described from the neighborhood of the village Kiran, Kyakhta region of the Buryatia Republic. Later it was found also on sand hills $26 \mathrm{~km}$ away along Kieran- 
Thamir Road. In Mongolia it is known only from the Mongolo-Daursky botanikogeographic region, occurs on the Selenga River, the Orkhon River, in the neighborhood of the settlement Shamar (UBA, MW, LE). We also found it in the valley of the Orkhon River: "Mongolia, aimag Selenge, Sum Shaamar, in the valley of the Orkhon River, N $50^{\circ} 06.675^{\prime} \mathrm{E} 106^{\circ} 11.584^{\prime}, \mathrm{H}=620 \mathrm{~m}$, on sand hills, 24.06.2012, N. Vlasova, V. Doronkin " (NSK). It has been found in low-specific community, projective covering 20\%: V. tsydenii sol., Leymus littoralis (Griseb.) Peschkova - sp., Thymus baicalensis Serg. - sp., Asparagus gibbus Bunge - sol. The species is concentrated only in the basin of the Selenga River, which flows from the South to the North across the territory of Mongolia and Southern Siberia.

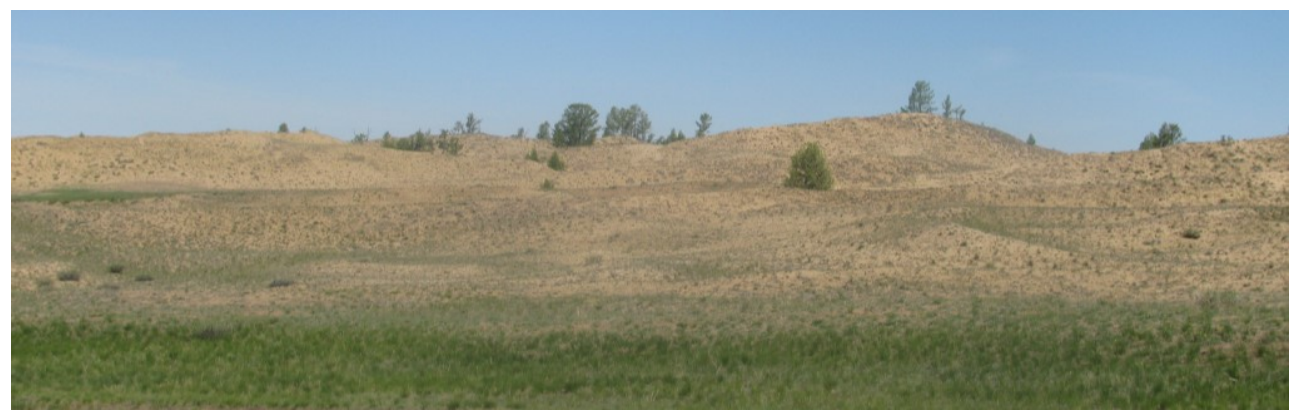

Fig 1. Altan-Els sands
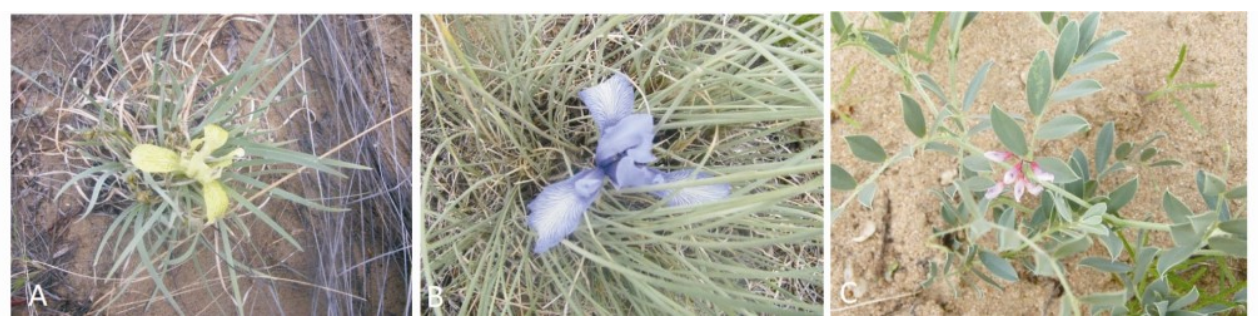

Fig. 2. A) Iris psammocola Y.T. Zhao B) Iris loczyi Kanitz C) Vicia tsydenii Malyschev

\section{References}

1. R.V. Kamelin, Bot. Zhurn., 72 (1987)

2. N.I. Akzhygitova, S.-W. Breckle, G. Winkler, E. A. Volkova, W. Wucherer, L. Ja. Kurochkina, G. B. Makulbekova, N.P. Ogar, E.I. Rachkovskaya, I.N. Safronova, V.N. Khramtsov, Botanical geography of Kazakhstan and Middle Asia (desert region) (St. Petersburg, 2003)

3. V.M. Hanminchun, N.V. Sedel'nikova, N.V. Perova, Flora Cuger-Jeliss Ubsunurskoj kotloviny (Barnaul, 1997)

4. V.M. Doronkin, D.N. Shaulo, Bot. J., 92, 435 (2007)

5. I.M. Gadghiev, A.Yu. Korolyuk, A.A. Tytlyanova et al., Steppes of Inner Asia (SB RAS Publisher, Novosibirsk, 2002)

6. L. Enkhtuya, T. Munkh-Erdene, Sci. Proc. Inst. Bot. Mongolia, 25, 174 (2013)

7. M. Urgamal, B. Oyuntsetseg, D. Nyambayar, Ch. Dulamsuren, Conspectus of the vascular plants of Mongolia (“Admon Printing” Press., Ulaanbaatar, 2014)

8. N.A. Dulepova, A.Yu. Korolyuk, Rast. Mir Az. Rossii, 2 (10) (2012) 